propahul [Methodological approaches of plant sort evaluation using of resistance to plant fungal pathogens]. Ahroekolohichnyi zhurnal - Ahroecological journal, 3, 90-93 [in Ukrainian].

16. Parfenyuk, A.Í. (2009). Sorti síl's'kogospodars'kikh kul'tur, yak faktor bíokontrolyu fítopatogennikh míkroorganízmív v agrofítotsenozakh [Sorts of crops as factor of biocontrol of pathogenic microorganisms in agrophytocenoses]. Ahroekolohichnyi zhurnal-Ahroecological journal, Special Issue, 248-250 [in Ukrainian].

17. Parfenyuk, A.Í., Kulinich, V.M., Krut', V.Í. (2009). Sorti buryaka stolovogo, yak faktor bíokontrolyu fítopatogennikh míkroorganízmív [Sorts of red beet as a factor of biocontrol of pathogenic microorganisms] Ahroekolohichnyi zhurnal - Ahroecological journal, Special Issue, 251-253 [in Ukrainian].

18. Parfenyuk, A.Í., Chmíl', O.M., Pasinok, Í.V. (2009). Chisel'níst' fítopatogennikh gribív na líníyakh ta gíbridakh ogírka [Number of plant pathogenic fungi on lines and hybrids of cucumber]. Ahroekolohichnyi zhurnal - Ahroecological journal, Special Issue, 254-255 [in Ukrainian].

19. Parfenyuk, A.Í., Beznosko, Í.V., Gorgan, M.D. (2012). Vpliv sortív í gíbridív pertsyu solodkogo na íntensivníst' sporoutvorennya fítopatogennikh gribív rodu Fusarium [The influence of sorts and hybrids of sweet pepper on intensity of spore reproduction of plant pathogenic fungi from genus Fusarium]. Naukovyy visnyk NUBiP - Scientific Journal of NULAS, 178, 59-64 [in Ukrainian].

20. Sterlikova, O.M. (2013). Formuvannya populyatsiy fitopatohennykh hrybiv pid vplyvom sortiv ta hibrydiv ohirka $\mathrm{v}$ ahrofitotsenozakh [Formation of plant pathogenic fungi populations under influence of cucumber sorts and hybrids in agrophytocenoses]. Extended abstract of Candidate's thesis. Kyiv [in Ukrainian].

21. Beznosko, I.V. (2013). Rol' askorbinovoyi kysloty i tsukriv u vzayemodiyi sortiv pertsyu solodkoho ta mikromitsetu Alternaria solani (Ell. et Mart.) [The role of ascorbic acid and sugar in interaction of sweet pepper sorts and micromycete Alternaria solani (Ell. et Mart.)]. Ahroekolohichnyi zhurnal - Ahroecological journal, 4, 130-132 [in Ukrainian].

22. Blahinina, A.A. Ekolohichni osoblyvosti vzayemodiyi henotypiv pshenytsi ta patotypiv fitopatohenykh hrybiv [Ecological features of wheat genotype interaction with pathogenic types of fungi]. Extended abstract of Candidate's thesis. Kyiv [in Ukrainian].

23. Blahinina, A.A., Parfenyuk, A.I. (2013). Vplyv metabolitiv roslyn riznykh sortiv pshenytsi ozymoyi na intensyvnist' propahuloutvorennya hrybiv Fusarium oxysporum Schlecgt. ta Alternaria tenuis Ness. et Fr. [The influence of metabolites of different sorts of winter wheat on intensity of sporulation of Fusarium oxysporum Schlecgt. and Alternaria tenuis Ness. et Fr.]. Ahroekolohichnyi zhurnal - Ahroecological journal, 2, 87-90 [in Ukrainian].

24. Parfenyuk, A., Sterlikova, O., Beznosko, I., Krut', V. (2014). Osobluvosti vzaemodii bakterialnogo shtamy Micrococcus luteus LBK1 z roslynamy sortiv/hibrydiv ohirka ta pertsyu solodkoho ta hrybom Fusarium oxysporum Scelecht [Features of interaction of bacterial strain Micrococcus luteus LBK1 with sorts/hybrids of cucumber and sweet pepper and fungus Fusarium oxysporum Scelecht]. Mikrobiolohichnyy zhurnal - Microbiological journal, 1, 33-37 [in Ukrainian].

\title{
SOIL FUNGI AS A BIOTIC FACTOR AFFECTING ON THE PLANTS
}

\section{E. Kopylov, O. Nadkernichna}

\section{Інститут сільськогосподарської мікробіології та агропромислового виробництва НААН}

Наведено сучасні погляди на роль грунтових грибів у мікробно-рослинній взаємодії. Визначення взаємовідносин грибів з рослинами можуть бути науковим підгрунтям для розробки засад оптимізації функціонування симбіозів і асоціацій мікроорганізмів $з$ рослинами, що відкривають шлях як до створення нових екологічно безпечних мікробних препаратів, так і для їх практичного використання у рослинництві.

Ключові слова: грунтові гриби, симбіоз, ендофітна асоціація, мікориза, фітогормони, фітотоксичні речовини.

Soil fungi are presented by different taxonomic units belonging to certain environ-

(c) E. Kopylov, O. Nadkernichna, 2017 mental groups which differ by feeding type and interaction with other organisms. Among them saprophytes destroying plant and animal residues, facultative and obligate plants 
parasites, mycorhiza-forming and predator fungi occur. Soil fungi are presented by all mentioned classes: Phycomycetes, Ascomycetes, Basidiomycetes, Deuteromycetes.

Fungi play an important role in organic compounds transformation, first of all - cellulose, lignin and pectin. Also they have significant role in nitrogen cycle, particularly ammonification processes, making conditions for development of other microorganisms. Besides, the soil fungi are able to produce different biological active substances: amino acids, enzymes, lipids, polysaccharides, antibiotics, plant growth stimulants, vitamins and toxic substances.

The soil fungi have an adsorptive type of nutrition; therefore they are closely associated with the substrate and have a large absorption surface. Fungi are characterized by their filamentous structure, rapid growth of mycelium apex at length and active metabolism. This promotes for fast substrate colonization, and possibility for producing antibiotic and toxic substances increases their competitiveness according to substrate adaptation. Using substrate fungi metabolism is decelerating and chlamydospores, sclerotiums or another dwell structures are formed. Spores can be easily transferred from one to another substrate, which provides high adaptability of fungi for environmental conditions.

Depending on substrate decomposition a succession of fungi species is taking place presented by facultative parasites (fungi penetrating in plant roots), saprophytic fungi (which absorb readily available substances: sugars, starch, hemicellulose) and fungi that destroy cellulose and lignin.

Facultative parasites penetrating in plants roots proceed to exist there for some time after the root death. Their parasitism lies in the verge of saprophytic existence, and they are mainly presented by fungi of the genus Fusarium, Pythium, Corticium, as well as some types of Cladosporium. Their mycelium grows on root surface and opens the way for invasion by saprophytic fungi which absorb readily accessible substances and rapidly take over the space among the dead plant residues. Being unable to compete with them, facultative parasites change over to the resting stage. The main feature of saprophytic fungi that rapidly appropriate readily accessible carbohydrates is active mycelia growth, rapid spores' germination and dormant forms in the presence of a suitable substrate. In the first place these fungi include class Zygomycetes, generally Mucorales molds, and some types of imperfect fungi, particularly Penicillium, Aspergillus and other genus. Many of them are characterized by the ability to form antibiotics and toxic substances, which creates more opportunities to fight for nutritional resources [1].

Cellulose decomposing fungi grow slower and cannot compete with fungi that rapidly assimilate easily available carbohydrates. This group includes members of ascomycetes and imperfect fungi. The most active cellulose destroyers are Ascomycetes and Deyteromicetes. Among them there are Fusarium, Aspergillus, Penicillium, Stachybotrys, Trichoderma, Cladosporium genus. For the most fungi hyphal growth is one from many examples of morphological structure adaptation to the substrate conformation. Basidiomycetes belong to the group destroying lignin. They grow slowly and begin to develop when all come-at-able carbohydrates are used. There is an evidence that some types of deyteromicetes are also able to decompose lignin. There are Trichoderma, Fusarium, Aspergillus, Penicillium among them. As far as plant pickings being destroyed fungi utilizing specific humus substances begin to develop. Usually they don't require a large amount of nutrients [2, 3].

Fungi distribution on the root surface (in rhyzoplana) is not only the result of substrate specificity, but it also depends on fungi competitive abilities. The roots surface contains both saprophytic fungi and facultative parasites. They grow rapidly, form extracellular enzymes actively, destroy the host plant cells penetrating into them, but they may change a type of nutrition to saprophytic. They are also considered as soil fungi, although many of them can be found as soil dormant stage and germinate only under the influence of root exudates. In plant rhizosphere, where favorable conditions for the most plants and 
microorganisms are created thanks to ekzosmos the content of fungi is much greater than in soil without plants. The specificity of root secretions determines the composition of rhizosphere fungi species. Fungal communities depend on physiologically active substances secreted by the root cells. Rhizosphere microorganisms, in turn, affect the plant through the root system, producing growthregulated substances.

\section{Phytohormonal impact of fungi on plants.}

It used to suppose that coordination of regulation system, the processes of growth integration and development of plants is effected by means of plant hormones, which are synthesized by specialized plants tissues and operate in extremely small doses. Later it was proved that many microorganisms which closely interact with plants are also capable to synthesize phytohormones. For today phytohormones are considered to be specific mediators of communication between host plants and microflora associated with it $[4,5]$.

Synthesis of phytohormones is inherent to rhizosphere, epiphytic and symbiotic microorganisms stimulating and improving plant growth and development. At the same time phytohormones are synthesized also by pathogenic microorganisms, whereby in amounts that greatly exceed plant needs. This type of phytohormones hypersynthesys by pathogens unbalances plant hormonal system and becomes a factor of many diseases [6-8].

It is known that higher plants contain several important classes of hormones: auxins, gibberellins, cytokinins, abscisic acid and ethylene. Recently brasin (brassinosteroid) and jasmon acid are included to them. Conventionally, auxins, gibberellins cytokininsand partly brasinscan be attributed to the stimulating substances, while abscisic acid, ethylene and zhasmon acid are the inhibitors.

Auxins are the first phytohormones that were investigated. Auxins are responsible for the plant cells and tissues division and differentiation. They stimulate seeds and tubers germination, accelerate root-made processes and coordinate vegetative growth, tropisms and fruitification. They influence on photo- synthesis, pigments formation, biosynthesis of metabolites and plant resistance to environmental stress factors. The greatest biological activity has indolyl-3-acetic acid (IAA). Also there are another compounds with auxin activity which are indoles in most cases and similar to the IAA by chemical structure. These indole compounds can be the precursors of indolyl-3-acetic acid, or the products of its further transformation.

Molds of genus Fusarium, Rhizoctonia, Rhizopus, Absidia, Aspergillus, Penicillium, Monilia, Phoma, Pythium, Trichoderma, Actinomucor, Amanita can produce auxins, such as indolyl-3-acetic acid. The ability to synthesize IAA is inherent for many pathogenic fungi genus such as Taphrina, Phytophtora, Ustilago, Alternaria, Fusarium, Plasmodiophora, Colletotrichum, Phymatotrichum, Lentinus, Sclerotium, Monilia, Rhizoctonia. Mycorrhizal fungi of genus Laccaria, Pisolithus, Amanita, Rhizopogon, Paxillus, Hebelota also synthesize IAA [7-12].

Despite the fact that plants and microorganisms are able to synthesize IAA, different ways of its formation exist. Thus, in plant cells IAA is generated de novo from tryptophan by oxidative deamination through indolyl-3pyruvic acid and indole-3-acetaldehyde, or by generation of an intermediate product - tryptamine through indole-3-acetaldehyde [13].

Microorganisms have 5 different ways of IAA biosynthesis, and only three of them inherent to fungi. Thus, the majority of Fusarium, Rhizoctonia and Colletotrichum phytopathogenic molds have the most common way of IAA formation through indolyl-3-pyruvic acid and indole-3-acetaldehyde. For unidentified fungi forming mycorrhiza with orchids is typical alternative way of IAA synthesis via tryptamyne. Some pathogenic fungi of genus Colletotrichum have biosynthesis of IAA occuring via indolyl-3-acetamide $[5,6,10,11]$.

In plants IAA is bound with sugars, amino acids and proteins making inactive (reserve) forms. If necessary, phytohormones release and regain their physiological activity. Some fungi (Pisolithus iutinctorius and Paxillus involutus) are also able to produce bound forms of indolyl-3-acetic acid [5, 14]. 
A lot of fungi are characterized by presence of several ways auxin biosynthesis expanding their ecological abilities in formation of associations and symbioses with plants. Epiphytic and rhizosphere molds have the leading role in conversion of tryptophan, which is contained in plants' exudates to indolyl-3-acetic acid. Adding the tryptophan into the medium where molds being grown can increase biosynthesis of auxins in ten times. The ability to produce IAA actively is a strain feature of the microorganisms.

Among fungi within the same genus and even species high activity strains and strains with law activity of indolyl-3-acetic acid biosynthesis occurred, and also can happen the strains which do not generate the IAA.

Auxins make a stimulating effect on growth and development not for only plants but also for microorganisms. First of all, this is nitrogen-fixing bacteria of Rhizobium, Azotobacter, Azospirillum and Bacillus genus [5, 15].

Gibberellins are the most common group of phytohormones among plants and microorganisms, which number is more than 100 compounds. Gibberellins belong to the class of terpenes and consist of isoprene residues that form four rings as usual. Gibberellic acids HK3, HK7, HK1 and HK4 are the most common and biologically active phytohormones of this group.

The effects of gibberellins aimed at division and elongation of cells that form a part of intercalary meristem, stimulating flowering, activation of membrane synthesis and starchsplitting enzymes. Unripe seeds are characterized by the highest content of gibberellins in plants. Different stages of plant ontogenesis can differ by contents and set of gibberellins. Gibberellins are synthesized in different parts of plants, but generally in leaves [13].

The ability of gibberellins' biosynthesis is detected among all groups of microorganisms, but the most active producers, capable to form more than $1000 \mathrm{mg} / \mathrm{l}$ of gibberellic acid are the molds Phaeosphaeria and Gibberella fujikuroi. The molds belong to species Aspergillus flavus, A. niger, Penicillium corylophilum, P. cyclopium, P. funiculosum, Verticillum sp., Rhizopus stolonifer, Shizophillum commune also capable to produce gibberellins. Active producers of gibberellins occur among pathogenic fungi: Ustilago mayis, Sphaceloma manihoticola, Cercospora rosicola, Botryodiplodia theobromae, Fusarium semitectum, $F$. acuminatum, F. anguioides, $F$. avenaceum, F. chlamydosporum, F. equiseti, F. osysporum, F. moniliforme. Some different gibberellic acids (HK3, HK7, HK4, HK13) were found in conidias of $F$. graminearum straight after 2:00 hours of spores incubation $[5,16]$.

Investigations of gibberellins production among plants and molds indicate that during the evolution plants and molds being formed the independent biosynthetic routes of phytohormones of this group.

Cytokinins are the adenine derivative by their chemical structure. Physiological activity of cytokinins differs depending on structure of molecule purine ring. This explains the fact that cytokinins regulate various physiological processes: activate RNA and protein synthesis in cells with activation of RNApolymerase, stimulate plant cell division, promote branching and stimulate seed germination, regulate the formation of chloroplasts, increase stability of photosynthetic apparatus during the water stress, contribute to cells stability residing in adverse environmental conditions [5].

Microorganisms capable to synthesize cytokinins are kynetyn, zeatyn, izopenteniladenin and some others. Compounds with cytokinin activity are educed in molds of genus Paxillus, Rhizopogon, Suillus (forming mycorrhiza with plants) as well as pathogenic fungi belonging to the genus Uromyces, Schizophyllum, Taphrina $[9,17]$.

For a long time plants failed to identify genes of cytokinins biosynthesis. This gave a reason to doubt that plants actually create these hormones, but in 2001 Arabidopsis thaliana was explored the genes that encode functionally active key of cytokinins enzyme isopentenyltransferase biosynthesis were identified $[4,9]$. The same genes were also found in bacteria and pathogenic fungi such as Taphrina cerasi $[9,18]$.

Exogenous cytokinins stimulate microorganisms' antibiotic, amino acids and some 
enzymes biosynthesis and also affect on content of endogenous phytohormones in microorganisms. It is important that mixed culture of microorganisms form a larger number of auxins, gibberellins and cytokinins than pure cultures. As a result, biosynthesis of phytohormones has been increasing greatly in presence of microorganisms' associations interacting with plants $[9,18,19]$.

Plants' metabolites exuding in rhizosphere contain a variety of biologically active compounds that are the source of microorganisms nutrition, phytohormones can be signal molecules for harmonizing interactions between plants and rhyzosphere microorganisms. For example, the interaction with plants in root exudates containing tryptophan biosynthesis of auxins by microorganisms also increases, because tryptophan is a precursor of auxins and rhyzosphere plant microflora has a key role in its transformation into IAA. Synthesized by microorganisms phytohormonal substances, in turn, affect both the plant and the producers. Therefore plants and associated microorganisms that inhabit one ecological niche should be considered as a solitary system. However, each participant in this system is characterized by its own biochemical activity, and finally synthesizes the same plant hormones, the difference of which is in concentration only. In struggle for existence, those rhizosphere microorganisms receive benefits which can secrete phytohormones, that allows them to colonize rhizosphere soil, root surface and penetrate into the internal plant tissues more successfully $[9,20]$.

The activity of phytohormones produced by molds is provided by their interaction with specific receptors (allosteric proteins) that recognize plant hormones, specifically bind with it, forming a hormone-receptor complex. This complex transmits signals required to run cell appropriate physiological response. It is important that the same hormone can connect to different receptors, causing under different physiological responses. This fact explains the reasons of phytohormones multifunctional action. Phytohormones influence on the so-called «competent» cells, and their competence is determined by the presence of specific receptors [13].

\section{Soil fungi-producers of phytotoxic substances.}

Soil molds are able to synthesize phytotoxins depressing growth and plants' development as well as they produce different kinds of phytohormones.

A lot of soil microorganisms are characterized by phytotoxic activity. Thus, among all the selected soils microorganisms in chernozem soils $11-28 \%$ occurs, in sod-podzolic soils - 32-38\% phytotoxic microorganisms [21, 22]. Largely content of phytotoxic microorganisms depends on agriculture kind. In cultivated soils their content is much less than in virgin soils. Particularly, strong influence on phytotoxic microorganism content has permanent crops growing and their high rotation. In addition, the content of phytotoxic microorganisms depends on soil type, degree of cultivation, farming practices and vegetation characteristics [23, 24].

Despite the fact that ability to produce phytotoxic substances was found in many types of soil microorganisms, phytotoxic substances are isolated and characterized only for certain types. This is due to the fact the establishment of the secondary metabolites chemical structure is quite a challenge. Instability and lability of many phytotoxic substances in soil further complicates the problem.

In 1970 T. Mirchynk proposed a division between toxins, phytotoxins and antibiotics undertaken on the basis of concentrations within their effect on the object. This approach has been very effective. On this basis active phytotoxins can be compounds in concentrations that do not override $100 \mathrm{mkg} / \mathrm{ml}$ negative effect on plants, without showing effects on animals and microorganisms. It belongs to phytoxins-antibiotics group when phytotoxic and antibiotic effect is expressed within the compound concentrations up to $100 \mathrm{mg} / \mathrm{ml}$. Thus, viktorin is the typical phytotoxin because its activity expresses in concentration of $0.02 \mathrm{mkg} / \mathrm{ml}$, while it does not influence on animals and microorganisms. As well, fusaric acid is the typical phytotoxin because its phytotoxic activity expresses in 
concentration of $0.1-5.0 \mathrm{mkg} / \mathrm{ml}$, while antibiotic activity occurs only in concentration of $500 \mathrm{mkg} / \mathrm{ml}$. Generally, the majority of soil molds toxic compounds can be attributed to phytotoxins-antibiotics [21].

Mold phytotoxic substances related to the chemical nature of peptides or amino acid derivatives were investigated. These compounds are formed by phytopathogenic molds as usually and characterized by high biological activity and specificity for hostplant. This group includes viktorin (producer - Helminthosporium sp.), HC-toxin (producer - Helminthosporium sp.), alternarin (producer - Alternaria sp.), tentoxin (producer - Alternaria alternaria), AM-toxin (producer - Alternaria mali) and others [1].

Some saprophytic molds from genus $A s$ pergillus produce malformin, its phytotoxic activity is detected in concentrations of $0.1-$ $0.2 \mathrm{mkg} / \mathrm{ml}$. By its chemical structure malformins are cyclical pentapeptides, consisting of cysteine, valine, leucine at different ratios [1, 25, 26].

Phytotoxic activity towards to tomatoes, potatoes and grapes has some amino acids derivatives like lycomarasmine (some species of Fusarium are producers) and lycomarasmine acid (some species of genus Fusarium, Aspergillus, Colletotrichum, Pyrenophora are producers) [27, 28].

Some soil molds (mainly phytopathogenic fungi) form compounds related to glycopeptides and other carbohydrates derivatives. This group of substances (producers Helminthosporium sp.) and other phytotoxins is characterized by high activity and specificity for certain plants (producers - Helminthosporium maydis, Phomatra cheiphila, Phialophora cinerescens, Verticillium dahliae, some species of Cladosporium). All the above-mentioned toxins, occurring high activity against plants do not act on microorganisms, namely they are typical phytotoxins [1, 28].

Pathogenic microorganisms toxins are intensively studied due to their role in the plants pathogenesis. There is a great interest to toxins of soil saprophytic microorganisms. But unlike pathogenic microorganisms these molds produce phytotoxic compounds which are in the same concentrations have negative effect on the microorganisms. So they are phytotoxins-antibiotics.

Patulin is the most studied phytotoxinantibiotic (producers - Penicillium and Aspergillus), citrinin (producers - Penicillium and Aspergillus), penicilloic acid (producers Penicillium and Aspergillus), rubratoxin (producer - Penicillium purpurogenum), alternaric acid (producers - Alternaria tenuis and Alternaria solani) and others [1, 25, 26, 28].

Saprophytic microorganisms are also able to synthesize typical phytotoxins that don't demonstrate antibiotic activity. Thus, the soil molds of Chaetomium and Gliocladium genus produce phytotoxic substances with active concentration of range $5-10 \mathrm{mkg} / \mathrm{ml}$ according to a wide range of crops. These are glycolipids and ketones by their chemical structure. The action of phytotoxic effects is in violation of plant cells penetration mechanism, reducing cell growth in stretching zone. Besides, the profound violation in nuclear cell takes place: structural changes of chromosomes occur, vacuolation of nuclear and their lizis also can happen [29].

Aflatoxins are the group of compounds similar to dihydrofuran (coumarin). Some species of Aspergillus produce them. Aspergillus flavus is the most active toxin-maker. At low concentrations these compounds are toxic to warm-blooded animals, fish, insects and microorganisms, thus they can be described as toxins-antibiotics [1, 25, 28].

Heterocyclic compounds containing nitrogen have a high phytotoxic activity. Among them there are picolinic acid, fusaric acid (which is a derivative of picolinic acid) and viridikatin. Pseudomonas (P. putida) bacteria can be active producer of picolinic acid. Different species of Fusarium molds produce picolinic and fusaric acids. Phytotoxic effect of these compounds is in the range of 1$10 \mathrm{mkg} / \mathrm{ml}$, cotton and tomato plants are particularly susceptible to them [1].

From Dendrodochium toxicum individual substances called Dendrodochium mold toxin I, II, III, IV were isolated. The substances demonstrate strong toxic properties and cause disease, called Dendrodochiotoxicosis. At the 
same time the substances were characterized by phytotoxic properties (active concentration of $30 \mathrm{mkg} / \mathrm{ml}$ ) in relation to seedlings of oats, barley, lupine, beans. The most sensitive to the toxic actions were cabbage and radishes. The chemical nature of the toxins were terpenoids (macrocyclic compounds), rather trichothecenes [30].

The complex of highly toxic metabolites produced by the mold Stachybotrys alternansis called Stachybotrys-toxin. Considering the highly toxic activity toward to animals and humans Stachybotrys-toxin demonstrates phytotoxic activity, provokes necrosis and death of plant tissues, and inhibits germination of crops. The chemical nature of Stachybotrys-toxin belongs to steroids [28].

Carbocyclic terpenes produced by Fusicoccum amygdali also have a strong phytotoxic effect on tomato plants, peaches and almonds.Fusicoccin, allofusicoccin and isofusicoccin are known among them. By their chemical structure they are similar, but differ by their phytotoxic activity. Thus, the active fusicoccin concentration is 2 , allofusicoccin 20 , isofusicoccin $50 \mathrm{mkg} / \mathrm{ml}$ [1].

Many species of soil molds (Aspergillus niger, Penicillium oxalicum, $P$. citrinum, $P$. arenaria, P. luteus, Sclerotinia sclerotiorum) produce oxalic and citric acids, which phytotoxic effects appeared in concentrations of 250$300 \mathrm{mkg} / \mathrm{ml}$ on vetch plant, lupine and peas. Dibasic unsaturated fumaric acid was isolated from the culture liquid of Rhizopus sp. - almond roots and branches pathogen. Effect of pure fumaric acid causes the same symptoms. The mold Rhizoctonia solani produces phenylacetic and hydroxyphenylacetic acids demonstrating phytotoxic effects at doses of $5-50 \mathrm{mkg} / \mathrm{ml}$ to rice, cotton, sugar beet and lucerne. Penicillium molds are capable to produce salicylic and cinnamic acid, which phytotoxic activity occurs at the concentration within 150-200 mkg/ml, [1, 25-27, 31].

Disclosure of the interaction features between phytotoxic molds, other units of rhizosphere microbiota and plants has essential scientific and practical importance. The toxic substances of microbial origin have practical usage in breeding the new varieties and crop hybrids resistable to diseases and adverse environmental factors of creation an artificial infectious background. Their usage is justified by the fact that phytotoxins are able to decompose quickly and not to be accumulated in soil and other substrates, which is very important for the environment safety.

\section{The symbiosis between fungi and plants (mycorrhiza).}

Many of soil fungi are able to engage into close symbiotic relationships with plants, forming mycorrhiza. According to the literature sources of last decades mycorrhizal symbioses between fungi and plants are widespread and comprehend up to $85 \%$ of vascular plants on the Earth.

According to modern appreciation mycorrhiza is a structural formed mutualistic symbiotic association between plant roots and fungi where the organisms coexist in mutually beneficial relationship.

The development of symbiosis between fungi and plants is a complex multistage process that involves recognition, signaling and interaction between fungi and plants. Mycorrhiza formation is mutually beneficial for both fungus and plant. However, plants are able to grow and develop without mycorrhizal fungi while fungal spores are able for only limited germination and hyphae growth without plants. This demonstrates that plant signals perfom the leading role to the symbiosis initiation. Last years a large number of attention was paid to studying signal interaction in processes of mycorrhiza forming. In spite of this the nature of plant signals of different stages is not described yet.

It was shown that some plant flavonoids are capable at the low concentrations stimulate arbuscular-vesicular mycorrhiza fungi growth. Estradiol is the most active among the flavonoids that make a stimulating effect on mycorrhizal fungi. There is information about the role of plant phytohormones, particularly cytokinins in mycorrhiza forming. Despite the results, most researchers believe that no flavonoids or plant hormones are the key signaling molecules in colonization of plant roots by mycorrhizal fungi. Perhaps un- 
known secondary metabolites of plants are acting this role [32].

During last years, much researching was devoted to studying the molecular processes that occur during mycorrhizae formation. Interaction between mycorrhizal fungi and plants is a complex process, implemented through the molecular mechanisms. During symbiosis formation and functioning the interaction between partners combining into supraorganismal genetic system occurs. Close integration between metabolic partners, formation of specialized symbiotic structures and reproductive velocity regulation by symbiont plant is the result of mentioned system. Symbiosis forming is a special development strategy evolutionarily related to the general morphological programs. It had been organized during the evolution process together with microorganisms [32-34].

Today several types of mycorrhizawere are described. Vesicular-arbuscularmycorrhiza is the most studied. It is usually formed by obligate symbiont fungi from class Zygomycetes order Glomales, genera Glomus and Sclerocystis. At various times the exhibitors of these genues were isolated from penitsetum roots tissues (Pennisetum pedicellatum Trin.), eucalyptus (Eucalyptus camaldulensis Dehnh.), white acacia (Faidherbia albida (Delile) A. Chev.), himonobambuku (Chimonobambusa quadrangularis (Fenzi) Markino), erehtytesu (Erechthites valerianifolia (Walf.) DC.), hinhobiloba (Gingobiloba L.), taro (Colocasi formosanum Hayata, Colocasia formosa-num TT Chang \& T. Chen) and rice (Oryza sativa L.) $[35,36]$.

Arbuscular mycorrhiza is characterized by arbusculs and vesiculs in plants' roots cortical cells. Straight hyphae and their swirls mostly aseptate can be identified in tissues. Colonization is occurred only in rhizoderma and root bark parenchyma. Fungi never penetrate into the vascular cylinder and meristem region [35]. Spores are formed in soil or in roots. In soil foliar hyphae are also developed forming the «external mycelium» [32].

Ectomycorrhiza is formed by Basidiomycetes, Ascomycetes and Zygomycetes fungi classes; they cover thick lateral roots with a dense mesh (mantle). Hyphae don't penetrate into root cells but there is septate mycelium among root cells. The level of chlorophyll is usually accrued in such case. Most of gymnosperms as usual as angiosperms of Pinaceae, Betulaceae, Dipterocarpaceae, Myrtaceae, Fagaceae and Rosaceae families form ectomycorrhiza [35].

Arbutoides mycorrhiza is formed by basidiomycetes, ascomycetes and zygomycetes fungi class together with Ericales plants. The most typical examples are strawberry tree (Arbutus unedo L.) forming mycorrhiza both with Arctostaphylos and Pyrola plants. The roots are covered with hyphal mantle like ectomycorrhiza but differ from it penetrating into root cells [36].

Monotropoides mycorrhiza is like arbutoides but Monotropaceae plants don't increase chlorophyll maintenance forming association with fumgi. Thus Tricholoma fungi form mycorrhiza with Pityopus and Allotropa plants. Basidiomycete Hydnellum form mycorrhizal symbiosis in biocenosis containing Hemitomes and Monotropsis plants. Monotropoidesmycorrhiza usually formed by Basidiomycetes, Ascomycetes and Zygomycetes fungi [36].

Ericoides mycorrhiza is formed by basidiomycetes and ascomycetes together with Ericales plants order, for example - Hymenoscyphus ericae. This type of mycorrhiza is characterized by penetrating hyphae into root cells and hyphae curls in root hair cells [36].

Orquidoides mycorrhiza is distinctive for the orchid plants (genera Gastrodia) which often suffer from chlorophyll deficiency and they are forced to join an association with $\mathrm{Ba}-$ sidiomycetes fungi. Fungi hyphae are braided around the orchid plants' roots inside and outside. Hyphae curls are present also in stems of plants [32].

Ectomycorrhiza and endomycorrhiza formed by Basidiomycetes, Ascomycetes and Zygomycetes fungi classes with gymnosperms and flowering plants is specific for them. Ectomycorrhiza fungi cover with dense mesh (mantle) thick lateral roots. Septate mycelium is growing among root cells. Ecten- 
domycorrhiza has been less studied. It is similar to endomycorrhiza but differ with its hyphae presenting inside root cells. Hyphal mantle also can be absent. Both ecto- and endomycorrhiza lead to rising up chlorophyll maintenance in plant leaves [32, 36].

Mycorrhiza formation is mutually beneficial process both for plants and fungi. Therefrom fungi get an access to products of plants' photosynthesis, at the same time fungal hyphae branch in soil giving the opportunity for mycorrhizal plants to rise up the bulk of soil available for them. Plants with mycorrhizal roots are better adapted to the environment. They are more protected from adverse environmental conditions including drought, negative temperature, salinity, soil and air pollution [37-40].

\section{Endophytic associations of sapro- phytic soil fungi with plants.}

It is well known that some saprophytic soil fungi of genus Trichoderma, Fusarium, Acremonium make endophytic associations with plants' roots. Herewith inherent specific structures are not formed and no signs of disease are observed [9].

During last years some statement appeared that Chaetomium fungi are able to exhibit endofit properties. It has been shown that Chaetomium globosum infects tissues of tropical cereals and legumes Glinus lotoides, Canavalia cathartica and Imperata cylindrica [42-44]. Using sequences analysis it was es- tablished that Chaetomium globosum had been present among complex of endophytic fungi infecting leaf tissues, stems and roots of pink periwinkle (Catharanthus roseus) [45].

We revealed that soil saprophytic mold Chaetomium cochliodes can form mycorrhiza with plants of spring wheat and soybeans. It grows rapidly on plants' roots forming carposomes on the root surface and hairs and penetrates into rhizoderma cells which can be the evidence of endophytic association between the mold and plants. It has all the hallmarks of mycorrhiza, namely ectendomycorrhiza. Chaetomium cochliodes produces phytohormonal substance referring to auxins and gibberellins by their action and different fatty acids. There is arachidonic acid among them. It activates systemic immune response of plants on the effect of pathogens and adverse environmental factors [46, 47].

Some endophyte fungi are known as producers of growth regulating substances and can be used as the basic for biological preparations creation [48]. Such kinds of biological preparations have a number of significant advantages on synthetic growth regulatory substances. They are cheaper and multifunctional in comparison with traditional. Also that fungi can produce not only phytohormones but another biological active compound such as amino acids, fatty acids, vitamins and so on which have positive influence on plants growth and development.

\section{LITERATURE}

1. Garrett S.D. Soil Fungi and Soil Fertility: An Introduction to Soil Mycology / S.D. Garrett. - Pergamon, 2013. - $164 \mathrm{p}$.

2. Борзова Н.В. Целюлозодеградуючі системи мікроорганізмів: біосинтез, властивості та структурнофункціональні особливості / Н.В. Борзова, Л.Д. Варбанець // Біотехнологія. - 2009. -Т. 2, № 2. - C. 23-41.

3. Handbook of Applied Mycology. - Vol. 1: Soil and Plants. - CRC Press, 1991. - 736 p.

4. Кулаева О.Н. Новейшие достижения и перспективы в области изучения цитокининов / О.Н. Кулаева, В.В. Кузнецов // Физиол. раст. - 2002. - T. 49, № 4. - C. 626-640.

5. Гормоны и гормоноподобные соединения микроорганизмов (обзор) / Е.А. Цавкелова, С.Ю. Климова, Т.А. Чердынцева, А.И. Нетрусов // При- кладная биохимия и микробиология. $-2006 .-$ Т. 42 , № 3. - C. 161-168.

6. Indole derivatives produced by the fungus Colletotrichumacutatum causing lime anthracnose and postbloom fruit drop of citrus / K.R. Chung, T. Shilts, U. Erturk et al. // FEMS Microbiology Letters. - 2003. - Vol. 226, No. 1. - P. 23-30.

7. Phytotoxicity of Indole-3-acetic Acid Produced by the Fungus, Pythium aphanidermatum / A. Shimada, S. Takeuchi, A. Nakajima et al. // Bioscience, Biotechnology, and Biochemistry. - 2000. - Vol. 64, No. 1. - P. 187-189.

8. Yurekli $F$. The synthesis of indole-3-acetic acid by the industrially important white-rot fungus Lentinussajor-caju under different culture conditions / F. Yurekli, H. Geckil, F. Topcuoglu // Mycological Research. - 2003. - Vol. 107, No. 3. - P. 305-309. 
9. Микроорганизмы-продуценты стимуляторов роста растений и их практическое применение (обзор) / Е.А. Цавкелова, С.Ю. Климова, Т.А. Чердынцева, А.И. Нетрусов // Прикладная биохимия и микробиология. - 2006. - Т. 42, № 2. C. $133-143$.

10. Biosynthesis and Secretion of Indole-3-Acetic Acid and Its Morphological Effects on Tricholomavaccinum-Spruce Ectomycorrhiza / K. Krause, C. Henke, T. Asiimwe et al. // Appl Environ Microbiol. 2015. - Oct.; No. 81(20). - P. 7003-7011.

11. In Planta Production of Indole-3-Acetic Acid by Colletotrichum gloeosporioides $\mathrm{f}$. sp. aeschynomene / R. Maor, S. Haskin, H. Levi-Kedmi, A. Sharon // Appl Environ Microbiol. - 2004 - Vol. 70, No. 3. - P. 1852-1854.

12. $W u J$. A preliminary study on ingredient of secretion from fungi of orchid mycorrhiza / J. Wu, J. Qian, S. Zheng // Ying Yong Sheng Tai XueBao. - 2002. - Vol. 13, No. 7. - P. 845-848.

13. Phytohormones In Botrytis-Plant Interactions / A. Sharon, Y. Elad, R. Barakat, P. Tudzynski. - Botrytis: Biology, Pathology and Control. - Springer Netherlands, 2007. - P. 163-179.

14. Niemi K. Häggman Ectomycorrhizal fungi and exogenous auxins influence root and mycorrhiza formation of Scots pine hypocotyl cuttings in vitro / K. Niemi, T. Vuorinen, A. Ernstsen // Tree Physiology. - 2002. - Vol. 22, No. 17. - P. 1231-1239.

15. Sergeeva E. Evidence for production of the phytohormone indole-3-acetic acid by cyanobacteria / E. Sergeeva, A. Liaimer, B. Bergman // Planta. - 2002. - Vol. 215. - P. 229-238.

16. Characterization of gibberellin producing strains of Fusarium moniliforme based on DNA polymorphism / N. Mitter, A. Srivastava, K. Renu et al. // Mycopathologia. - 2002. - Vol. 153, No. 4. P. $187-193$.

17. Janitor A. Growth of mycelia of phytopathogenic fungi after application of abscisic acid in in vitro conditions / A. Janitor // Plant Protection Science. - 2002. - Vol. 38, No. 3. - P. 94-97.

18. Chanclud E. Plant hormones: a fungal point of view / E. Chanclud, J.-B. Morel // Molecular Plant Pathology. - 2016. - No. 17 (8). - P. 1289-1297.

19. Vereecke D. The Rhodococcus fascians-plant interaction: morphological traits and biotechnological applications / D. Vereecke, S. Burssens, C. SimonMateo // Planta. - 2000. - Vol. 210, No. 2. P. 241-251.

20. Роль триптофана в корневых экзометаболитах для фитостимулирующей активности ризобактерий / Л.В. Кравченко, Т.С. Азарова, Н.М. Макарова, И.А. Тихонович // Микробиология. -2004. - T. 73, № 2. - C. 195-198.

21. Мирчинк Т.Г. Токсины почвенных и фитопатогенных грибов / Т.Г. Мирчинк // Сельскохозяйственная биология. - 1970. - Т. 5, № 5. C. 694-702.

22. Надкерничный С.П. Фитотоксические свойства микроскопических грибов почв Украины: Автореф. дис. ... канд. биол. наук / С.П. Надкернич- ный; Всес. науч.-иссл. ин-т с.-х. микробиологии. - Л., 1976. - 34 c.

23. Берестецкий O.A. Фитотоксины почвенных микроорганизмов и их экологическая роль / О.А. Берестецкий // Фитотоксические свойства почвенных микроорганизмов. - Л., 1978. - С. 7-15.

24. Щербаков А.П. Фитотоксичность почвенных микромицетов как параметр агроэкологического мониторинга / А.П. Щербаков, И.Д. Свистова // Сельскохозяйственная микробиология в XIXXXI веках: Всерос. конф. (С.-Петербург, 14-19 июня 2001 г.): Тез. докл. - СПб., 2001. - С. 41.

25. Advances in Aspergillus secondary metabolite research in the post-genomic era / J.F. Sanchez, A.D. Somoza, N.P. Keller, C. Wang. // Natural product reports. -2012 . - Vol. 29, No. 3. - P. 351371.

26. Zhelifonova V.P. Secondary metabolites in taxonomy of the Penicillium fungi / V.P. Zhelifonova, T.V. Antipova, A.G. Kozlovsky // Microbiology. - 2010. - Vol. 79, No. 3. - P. 277-286.

27. Nesic K. Fusarial toxins: secondary metabolites of Fusarium fungi / K. Nesic, S. Ivanovic, V. Nesic // Rev Environ Contam Toxicol. - 2014. - Vol. 228. - P. 101-120.

28. Ismaiel A. Mycotoxins: Producing Fungi and Mechanisms of Phytotoxicity / A. Ismaiel, J. Papenbrock // Agriculture 2015. - No. 5. - P. 492-537.

29. Надкерничная Е.В. Изучение химической природы и свойств фитотоксических веществ Gliocladium zaleskii Pidopl. 11313 и Chaetomium aureum 8583: Автореф. дис. ... канд. биол. наук / Е.В. Надкерничная; Ин-т микробиологии и вирусологии им. Д.К. Заболотного. - К., 1982. $27 \mathrm{c}$.

30. Микотоксины: прошлое, настоящее, будущее / А.М. Зайченко, И.Г. Рубежняк, Е.В. Андриенко и др. // Микробиол. журн. - 2003. - Т. 65, № 1-2. - C. 141-148.

31. Schmiedeknecht G. Erfolgreiche Anwendung microbieller Antagonisten zur biologischen Bekamfung von Rhizoctonia solani bei Kartoffel pflanzen / G. Schmiedeknecht // Mitt. Biol. Bundesanst. Land - und Forstwirt. - 1990. - No. 266. - P. 296.

32. Крипка A.В. Молекулярные и клеточные аспекты развития арбускулярных микоризных симбиозов и их значение в жизнедеятельности растений / А.В. Крипка, Б.В. Сорочинский, Д.М. Гродзинский // Цитология и генетика. - 2002. - № 4. - C. $72-81$.

33. Генетика развития растений / Л.А. Лутова, Н.А. Проворов, О.Н. Тиходеев и др. - СПб.: Наука, 2000. - 539 с.

34. The pre-symbiotic growth of arbuscular mycorrhizal fungi is induced by a branching factor partially purified from plant root exudates / M. Buee, M. Rossignol, A. Jauneau et al. // Molecular Plant-Microbe Interactions. - 2000. - Vol. 13. - P. 693-698.

35. Changing partners in the dark: isotopic and molecular evidence of ectomycorrhizal liaisons between forest orchids and trees. / M.I. Bidartondo, B. Burghardt, G. Gebauer et al. // Proceedings of 
the Royal Society of London. -2004. - Vol. 271. P. 1799-1806. - (Series: B, Biological Sciences).

36. Differential expression of Glomus intraradices genes in external mycelium and mycorrhizal roots of tomato and barley / G. Delp, S. Timonen, G. Rosewarne et al. // Mycological Research. - 2003. - Vol. 107. - P. 1083-1093.

37. Akiyama K. Plant sesquiterpenes induce hyphal branching in arbuscular mycorrhizal fungi / K. Akiyama, H. Matsuoka, H. Hayashi // Nature. - 2005. - Vol. 435. - P. 824-827.

38. Смит С.Е. Микоризный симбиоз / С.Е. Смит, Д.Дж. Рид; [Пер. с англ. Е.Ю. Ворониной]. - М.: Товарищество научных изданий КМК, 2012. $776 \mathrm{c}$.

39. Arbuscular mycorrhizae and water relations in maize under drought stress at tasseling / K.S. Subramanian, C. Charest, L.M. Dwyer, R.I. Hamilton // New Phytol. - 1995. - Vol. 129. - P. 643-650.

40. Strigolactones stimulate arbuscular mycorrhizal fungi by activating mitochondria / A. Besserer, V. Puech-Pages, P. Kiefer et al. // PLoS Biology. - 2006. - Vol. 4. - P. 1239-1247.

41. Characterization of an Aux AA cDNA upregulated in Pinus pinaster roots in response to colonization by the ectomycorrhizal fungus Hebeloma cylindrosporum / V. Charvet-Candela, S. Hitchin, D. Ernst et al. // New Phytologist. - 2002. - Vol. 154. P. 769-777.

42. Chaetoglobosin U, a cytochalasan alkaloid from endophytic Chaetomium globosum IFB-E019/
G. Ding, Y.C. Song, J.R. Chen et al. // J. Nat. Prod. - 2006. - Vol. 69. - P. 302-304.

43. El-Zayat S.A. Preliminary studies on laccase production by Chaetomium globosum an endophytic fungus in Glinus lotoides / S.A. El-Zayat // American-Eurasian J. Agric. \& Environ. Sci. - 2008. - Vol. 1, No. 3. - P. 86-90.

44. Seena $S$. Endophytic fungal diversity of 2 sand dune wild legumes from the southwest coast of India / S. Seena, K.R. Sridhar // Can. J. Microbiol. - 2004. - Vol. 50, No. 12. - P. 1015-1021.

45. The endophytic fungal complex of Catharanthus roseus (L.) G. Don / R.N. Kharwar, V.C. Verma, G. Strobel, D. Ezra // Current science. - 2008. - Vol. 95, No. 2 - P. 228-233.

46. Копилов С.П. Ефективність симбіотичної взаємодії гриба Chaetomium cochliodes Palliser з рослинами сої / С.П. Копилов, С.П. Надкерничний // Физиология и биохимия культурных растений. - 2008. - T. 40, № 3. - C. 260-267.

47. Копылов Е.П. Почвенные сапрофитные грибы природные регуляторы роста, развития и устойчивость растений к возбудителям болезней / Е.П. Копылов. - Palmarium academic publishing, AV Akademikerverlag GmbH\&Co.KG, 2013. - 104 c.

48. Новий комплексний препарат Біовітрекс-екстра та його рістстимулююча і фунгіцидна активність в дослідах з озимою пшеницею / I.В. Драговоз, В.К. Яворська, А.В. Богданович та ін. // Биологические препараты в растениеводстве. Radostim. - Kiev, 2008. - P. 109-113.

\section{REFERENCES}

1. Garrett, S.D. (2013). Soil Fungi and Soil Fertility: An Introduction to Soil Mycology. Pergamon [in English].

2. Borzova, N.V. \& Varbanets, L.D. (2009). Celulozodegradujuchi sistemy microorganizmiv: biosintez, vlastivosti ta strukturno-funkcionalni osoblyvosti [The cellulose degrading systems of microorganisms: biosyntesis, properties, structural and functional characteristics]. Biotehnologia - Biotechnology, 2, 2, 23-41 [in Ukrainian].

3. Handbook of Applied Mycology (1991). (Vol. 1). Soil and Plants [in English].

4. Kulaeva, O.N. \& Kuznetsov, V.V. (2002). Novejshie dostizhenija i perspektivy v oblasti izuchenija citokininov [The newest achievements and prospects in cytokinins investigation sphere]. Physiol. rast. Physiology of plants, 49, 4, 626-640 [in Russian].

5. Tsavkelova, E.A., Klimova, S.Yu., Cherdyintseva, T.A., Netrusov, A.I. (2006). Gormonyi i gormonopodobnyie soedineniya mikroorganizmov (obzor) [Hormones and hormone-like substances of microorganisms: A review]. Prikladnaya biohimiya $i$ mikrobmologiya - Applied Biochemistry and Microbiology, 42, 3, 161-168 [in Russian].

6. Chung, K.R. Shilts, T., Erturk, U., Timmer, L.W., Ueng, P.P. (2003). Indole derivatives produced by the fungus Colletotrichum acutatum causing lime anthracnose and postbloom fruit drop of citrus.
FEMS Microbiology Letters., Vol. 226, 1, 23-30 [in English].

7. Shimada, A., Takeuchi, S., Nakajima, A., Tanaka, S, Kawano, T, Kimura, Y. (2000). Phytotoxicity of Indole-3-acetic Acid Produced by the Fungus, Pythium aphanidermatum. Bioscience, Biotechnology, and Biochemistry, Vol. 64, 1, 187-189 [in English].

8. Yurekli, F., Geckil, H., Topcuoglu, F. (2003). The synthesis of indole-3-acetic acid by the industrially important white-rot fungus Lentinus sajor-caju under different culture conditions. Mycological Research, Vol. 107, 3, 305-309 [in English].

9. Cavkelova, E.A., Klimova, S.Y., Cherdynceva, T.A., Netrusov, A.I. (2006). Mikroorganizmy-producenty stimulyatorov rosta rastenij $\mathrm{i}$ ih prakticheskoe primenenie (obzor) [Microbial producers of plant growth stimulators and their practical use: A review]. Prikladnaya biohimiya i mikrobmologiya - Applied Biochemistry and Microbiology, 42, 2, 133-143 [in Russian].

10. Krause, K., Henke, C., Asiimwe, T., Ulbricht, A., Klemmer, S., Schachtschabel, D. et al. (2015). Biosynthesis and Secretion of Indole-3-Acetic Acid and Its Morphological Effects on Tricholoma vaccinumSpruce Ectomycorrhiza. Appl Environ Microbiol., 81, 20, 7003-7011 [in English].

11. Maor, R., Haskin, S., Levi-Kedmi, H., Sharon, A. (2004). In Planta Production of Indole-3-Acetic 
Acid by Colletotrichum gloeosporioides f. sp. aeschynomene. Appl Environ Microbiol., Vol. 70, 3, 1852-1854 [in English].

12. Wu, J., Qian, J., Zheng, S. (2002). A preliminary study on ingredient of secretion from fungi of orchid mycorrhiza. Ying Yong Sheng Tai Xue Bao, Vol. 13, 7, 845-848 [in English].

13. Sharon, A., Elad, Y., Barakat, R., Tudzynski, P. (2007). Phytohormones In Botrytis-Plant Interactions. Botrytis: Biology, Pathology and Control. Springer Netherlands [in English].

14. Niemi, K., Vuorinen, T., Ernstsen, A. (2002). Häggman Ectomycorrhizal fungi and exogenous auxins influence root and mycorrhiza formation of Scots pine hypocotyl cuttings in vitro. Tree Physiology, Vol. 22, 17, 1231-1239 [in English].

15. Sergeeva, E., Liaimer, A., Bergman, B. (2002). Evidence for production of the phytohormone indole3 -acetic acid by cyanobacteria. Planta, Vol. 215, 229-238 [in English].

16. Mitter, N., Srivastava, A., Renu, K., Ahamad, S., Sarbhoy, A.K., Agarwal, D.K. (2002). Characterization of gibberellin producing strains of Fusarium moniliforme based on DNA polymorphism. Mycopathologia, Vol. 153, 4, 187-193 [in English].

17. Janitor, A. (2002). Growth of mycelia of phytopathogenic fungi after application of abscisic acid in in vitro conditions. Plant Protection Science, Vol. 38, 3, 94-97 [in English].

18. Chanclud, E. \& Morel, J.-B. (2016). Plant hormones: a fungal point of view. Molecular Plant Pathology, 17, 8, 1289-1297 [in English].

19. Vereecke, D., Burssens, S., Simon-Mateo, C. (2000). The Rhodococcus fascians-plant interaction: morphological traits and biotechnological applications. Planta, Vol. 210, 2, 0241-0251 [in English].

20. Kravchenko, L.V., Azarova, T.S., Makarova, N.M., Tihonovich, I.A. (2004). Rol' triptofana v kornevyh ehkzometabolitah dlya fitostimuliruyushchej aktivnosti rizobakterij [The role of tryptophan in root exometabolites for the phytostimulating activity of rhizobacteria]. Mikrobiologiya - Microbiology, 73, 2, 195-198 [in Russian].

21. Mirchink, T.G. (1970). Toksiny pochvennyh i fitopatogennyh gribov [Toxins of soil and phytopathogenic fungi]. Sel'skohozyajstvennaya biologiya - Agricultural biology, 5, 5, 694-702 [in Russian].

22. Nadkernichnyj, S.P. (1976). Fitotoksicheskie svoistva mikroskopicheskikh gribov pochv Ukrainy [Phytotoxic properties of microscopic fungi of soils in Ukraine]. Extended abstract of candidate's thesis. Leningrad [in Russian].

23. Beresteckij, O.A. (1978). Fitotoksiny pochvennyh mikroorganizmov i ih ehkologicheskaya rol' [Phytotoxins of soil microorganisms and their ecological role]. Fitotoksicheskie svojstva pochvennyh mikroorganizmov [Phytotoxic properties of soil microorganisms]. Leningrad [in Russian].

24. Shcherbakov, A.P. \& Svistova, I.D. (2001). Fitotoksichnost' pochvennyh mikromicetov kak parametr agroehkologicheskogo monitoringa [Phytotoxicity of soil micromycetes as a parameter of agroecologi- cal monitoring]. Agricultural microbiology in the XIX-XXI centuries. All-Russia conf. '01: Tez. dokl. (pp. 41). St. Petersburg [in Russian].

25. Sanchez, J.F., Somoza, A.D., Keller, N.P., Wang, C. (2012). Advances in Aspergillus secondary metabolite research in the post-genomic era. Natural product reports, 29, 3, 351-371 [in English].

26. Zhelifonova, V.P., Antipova, T.V., Zhelifonova, V.P., Kozlovsky, A.G. (2010). Secondary metabolites in taxonomy of the Penicillium fungi. Microbiology, Vol. 79, 3, 277-286 [in English].

27. Nesic, K., Ivanovic, S., Nesic, V. (2014). Fusarial toxins: secondary metabolites of Fusarium fungi. Rev Environ Contam Toxicol., 228, 101-120 [in English].

28. Ismaiel, A. \& Papenbrock, J. (2015). Mycotoxins: Producing Fungi and Mechanisms of Phytotoxicity. Agriculture, 5, 492-537 [in English].

29. Nadkernichnaya, E.V. (1982). Izuchenie khimicheskoi prirody i svoistv fitotoksicheskikh veshchestv Gliocladium zaleskii Pidopl. 11313 i Chaetomium aureum 8583 [Studying of chemical nature and properties of phytotoxic substances Gliocladium zaleskii Pidopl. 11313 and Chaetomium aureum 8583]. Extended abstract of candidate's thesis. Kiev [in Russian].

30. Zajchenko, A.M., Rubezhnyak, I.G., Andrienko, E.V., Kobzistaya, O.P., Cyganenko, E.S. (2003). Mikotoksiny: proshloe, nastoyashchee, budushchee [Mycotoxins: past, present, future]. Mikrobiol. zhurn - Microbiol.Journal, Vol. 65, 1-2, 141-148 [in Russian].

31. Schmiedeknecht, G. (1990). Erfolgreiche Anwendung microbieller Antagonisten zur biologischen Bekamfung von Rhizoctonia solani bei Kartoffelpflanzen [Successful application of microbial antagonists for the biological control of Rhizoctonia solani in potato plants]. Mitt. Biol. Bundesanst. Land und Forstwirt - Biol. Bundesanst. Land and forestry, 266, 296 (in German).

32. Kripka, A.V., Sorochinskij, B.V., Grodzinskij, D.M. (2002). Molekulyarnye i kletochnye aspekty razvitiya arbuskulyarnyh mikoriznyh simbiozov i ih znachenie v zhiznedeyatel'nosti rastenij [Molecular and cellular aspects of the development of arbuscular mycorrhizal symbioses and their significance in the vital activity of plants]. Citologiya i genetika $-\mathrm{Cy}$ tology and Genetics, 4, 72-81 [in Russian].

33. Lutova, L.A., Provorov, N.A., Tihodeev, O.N. et al. (2000). Genetika razvitiya rastenij [Genetics of plant development]. Sankt-Peterburg: Nauka [in Russian].

34. Buee, M., Rossignol, M., Jauneau, A., Ranjeva, R., Becard, G. (2000). The pre-symbiotic growth of arbuscular mycorrhizal fungi is induced by a branching factor partially purified from plant root exudates. Molecular Plant-Microbe Interactions, Vol. 13, 693-698 [in English].

35. Bidartondo, M.I., Burghardt, B., Gebauer, G., Bruns, T.D., Read, D.J. (2004). Changing partners in the dark: isotopic and molecular evidence of ectomycorrhizal liaisons between forest orchids and 
trees. Proceedings of the Royal Society of London. Series B, Biological Sciences, Vol. 271, 1799-1806 [in English].

36. Delp, G., Timonen, S., Rosewarne, G., Barker, S.J., Smith, S.E. (2003). Differential expression of Glomus intraradices genes in external mycelium and mycorrhizal roots of tomato and barley. Mycological Research, Vol. 107, 1083-1093 [in English].

37. Akiyama, K., Matsuoka, H., Hayashi, H. (2005). Plant sesquiterpenes induce hyphal branching in arbuscular mycorrhizal fungi. Nature, Vol. 435, 824827 [in English].

38. Smith, S.E., Read D.J. (2012). Mycorrhizal Symbiosis (E.Y. Voronina, Trans). Moscow: A partnership of scientific publications KMK [in Russian].

39. Subramanian, K.S. Charest, C., Dwyer, L.M., Hamilton, R.I. (1995). Arbuscular mycorrhizae and water relations in maize under drought stress at tasseling. New Phytol, Vol. 129, 643-650 [in English].

40. Besserer, A., Puech-Pages, V., Kiefer, P., GomezRoldan, V., Jauneau, A., Roy, S. et al. (2006). Strigolactones stimulate arbuscular mycorrhizal fungi by activating mitochondria. PLoS Biology, Vol. 4, 1239-1247 [in English].

41. Charvet-Candela, V., Hitchin, S., Ernst, D., Sandermann, H.Jr., Marmeisse, R., Gay, G. (2002). Characterization of an Aux/AA cDNA upregulated in Pinus pinaster roots in response to colonization by the ectomycorrhizal fungus Hebeloma cylindrosporum. New Phytologist, 154, 769-777 [in English].

42. Ding, G., Song, Y.C., Chen, J.R., Xu, C., Ge, H.M., Wang, X.T. et al. (2006). Chaetoglobosin U, a cytochalasan alkaloid from endophytic Chaetomium globosum IFB-E019. J. Nat. Prod., Vol. 69, 302-304 [in English].
43. El-Zayat, S.A. (2008). Preliminary studies on laccase production by Chaetomium globosum an endophytic fungus in Glinus lotoides. American-Eurasian J. Agric. E Environ. Sci., Vol. 1, 3, 86-90 [in English].

44. Seena, S. \& Sridhar, K.R. (2004). Endophytic fungal diversity of 2 sand dune wild legumes from the southwest coast of India. Can.J. Microbiol., Vol. 50, 12, 1015-1021 [in English].

45. Kharwar, R.N., Verma, V.C., Strobel, G., Ezra, D. (2008). The endophytic fungal complex of Catharanthus roseus (L.) G. Don. Current science, Vol. 95, 2, 228-233 [in English].

46. Kopilov, E.P. \& Nadkernichnij, S.P. (2008). Efektyvnist' symbiotychnoyi vzayemodiyi gryba Chaetomium cochliodes Palliser z roslynamy soyi [The efficiency of symbiotic interaction of mold Chaetomium cochliodes Palliser with soybean plants]. Fiziologiya i biohimiya kul'turnyh rastenij - Physiology and biochemistry cultural plants, 40, 3, 260-267 [in Ukrainian].

47. Kopilov, E.P. (2013). Pochvennye saprofitnye griby - prirodnye regulyatory rosta, razvitiya $i$ ustojchivost' rastenij $k$ vozbuditelyam boleznej [Saprophytic soil fungi - natural regulators of growth, development and resistance of plants to disease agents]. Palmarium academic publishing, AV Akademikerverlag GmbH\&Co.KG [in Russian].

48. Dragovoz, I.V., Yavorska, V.K., Bogdanovych, A.V. (2008). Novyj kompleksnyj preparat Biovitreksekstra ta jogo rist stymulyuyucha i fungicydna aktyvnist $\mathrm{v}$ doslidax z ozymoyu pshenyceyu [The new integrated product Biovitreks-extra and its growth-stimulating and fungicidal activity in experiments with winter wheat]. Biologicheskie preparaty $v$ rastenievodstve. Radostim [Biological preparations in plant growing. Radostim]. Kiev [in Ukrainian]. 